\title{
IAMJ
}

INTERNATIONAL

AYURVEDIC

MEDICAL JOURNAL

\section{COMPARATIVE STUDY OF DASAMOOLA KWATHA AND DASAMOOLARISHTA WITH SPECIAL REFERENCE TO THEIR METHOD OF PREPARATION AND USES}

\author{
B. S. M. M. Sooriyaarachchi ${ }^{1}$, Vidya N. ${ }^{2}$, D. B. Vaghela ${ }^{3}$ \\ ${ }^{1}$ P.G. Scholar, ${ }^{2}$ P.G. Scholar, ${ }^{3}$ Associate Professor \& HOD; \\ Department of Shalakya Tantra, Institute for Post Graduate Teaching and Research in Ayurveda, \\ Gujarat Ayurved University, Jamnagar, India
}

Email: madhushisooriyaarachchi@gmail.com

https://doi.org/10.46607/iamj0807122020

(Published online: July 2020)

Open Access

(C) International Ayurvedic Medical Journal, India 2020

Article Received: 06/06/2020 - Peer Reviewed: 25/06/2020 - Accepted for Publication: 01/07/2020

Check for updates

\section{ABSTRACT}

Dasamoola denotes to a polyherbal Ayurvedic preparation containing ten specific roots of medicinal plants which include five tree species called 'Brihat Panchamula' and five shrub species called 'Laghu Panchamoola'. Dasamoola Kwatha and Dasamoolarishta are popular Dasamoola preparations in liquid form because of their therapeutic effects. Therefore, they have been widely used for various disease conditions in Ayurveda. Dasamoola Kwatha is the decoction of Dasamoola whereas Dasamoola is a content of the Kwatha of Dasamoolarishta. Dasamoola Kwatha is varying with the condition for which it is used. This conceptual study was conducted by studying Ayurvedic Kwatha preparation, Sandhana Kalpana according to the Ayurvedic textbooks with the objective to compare the important ingredients of Dasamoola Kwatha and Dashamoolarishta. Also, modern scientific knowledge was explored in this study. The results of present study suggest that Kwatha and Arishta are the most suitable dosage forms of Dasamoola for the treatment of various disease conditions. Further findings also support that the traditional uses of different varieties of Dasamoola Kwatha have been designed specifically to address the individualized disease condition. When preparing a medicine for an individual patient, the traditional medical practitioners ideally take into account as such things of the patient more importantly affected Dosha, strength of the digestive fire, body tissues affected and the accumulated toxins. This shows that the Ayurvedic and Traditional preparations are often 
complex in their composition which is responsible for various functions, such as balancing, stimulating, cleansing and nourishing which in turn stimulating the innate capacity of the body to heal itself.

Keywords: polyherbal, Brihat panchamula, Laghu panchamoola

\section{INTRODUCTION}

Dasamoola is a group of herbs containing two subgroups namely Brihath Panchamoola and Laghu Panchamoola. ${ }^{1}$ Brihath Panchamoola consists of five herbal roots namely Agnimantha (Clerodendrun phlomoidis), Bilva (Aegle marmelos), Shyonaka (Oroxylum indicum), Patala (Stereospermum suaveolens) and Gambhari (Gmelina arborea). Laghu Panchamula also consists of five herbal roots namely Shalaparni (Desmodium gangeticum), Prishniparni (Uraria picta), Brihati (Solanum indicum), Kantakarika (Solanum xanthocarpum) and Gokshura (Tribulus terrestris). Dasamoola Kwatha, is the decoction of these ten herbal roots. ${ }^{2}$ Dasamoolarista is the fermented liquid medicinal preparation according to Sandhana Kalpana in which Dasamoola is one of ingredients in the decoction (Kwatha) known as Drava Dravya of its production. ${ }^{3}$ Traditional medical practitioners use Dasamoola Kwatha \& Dasamoolarishta which contain different or added ingredients according need of individualized treatments.

\section{Aim \& Objectives}

- To evaluate the role of Dasamoola Kwatha and Dasamoolarishta which form part of the individualized treatments of traditional medical system.

- To compare the therapeutic benefits of Dasamoola Kwatha and Dasamoolarishta

- To evaluate the role of Dasamoola Kwatha with different ingredients and their specific Anupana used in many generations.

\section{Methodology}

This conceptual study was conducted by studying Ayurvedic Kwatha preparation, Sandhana Kalpana with relevant to the processes of preparation, methods of administration and therapeutic benefits according to the Ayurvedic textbooks. And also, it was intended to study the advantages of fermented liquors according to the concepts of modern science and to compare the benefits of Dasamoolarishtaya with the benefits of Dashamula Kwatha.

Table 1: Brihat Panchamoola ${ }^{4}$

\begin{tabular}{|l|l|l|}
\hline No & Sanskrit Name & Latin Name \\
\hline 1. & Bilva & Aegle marmelos \\
\hline 2. & Shyonaka & Oroxylum indicum \\
\hline 3. & Gambhari & Gmelina arborea \\
\hline 4. & Agnimantha & Clerodendrun phlomidis \\
\hline 5. & Patala & Stereospermum suaveolens \\
\hline
\end{tabular}

Table 2: Laghu Panchamoola ${ }^{5}$

\begin{tabular}{|l|l|l|}
\hline No & Sanskrit Name & Latin Name \\
\hline 1. & Kantakari & Solanum xanthocarpum \\
\hline 2. & Brihati & Solanum indicum \\
\hline 3. & Shalaparni & Desmodium gangeticum \\
\hline 4. & Prishniparni & Uraria picta \\
\hline 5. & Gokshura & Tribulus terrestris \\
\hline
\end{tabular}


Table 3: Rasapanchaka of Dasamoola ${ }^{6}$

\begin{tabular}{|l|l|}
\hline Rasa & Kashaya, Madhura \\
\hline Guna & Guru, Ruksha \\
\hline Virya & Ushna \\
\hline Vipaka & Katu \\
\hline Doshagnatha & Vata Kapha Shamaka \\
\hline
\end{tabular}

Dasamoolarishta ${ }^{7}$ : Dasamoola is a content of the Kwatha of Dasamoolarishta. Arishta is that in which fermentation is allowed to proceed for generating alcohol in the liquids and ingredients kept after boiling.

Table 4: Composition of Kwatha Dravya of Dasamoolarishta

\begin{tabular}{|c|c|c|c|}
\hline S.No & Sanskrit Name & Latin Name & Parts Used \\
\hline 1. & Bilva & Aegle marmelos & Roots \\
\hline 2. & Agnimantha & Clerodendrun phlomidis & Roots \\
\hline 3. & Shyonaka & Oroxylum indicum & Roots \\
\hline 4. & Patala & Stereospermum suaveolens & Roots \\
\hline 5. & Vartaki & Solanum indicum & Roots \\
\hline 6. & Kantakari & Solanum xanthocarpum & Roots \\
\hline 7. & Gokshura & Tribulus terrestris & Roots \\
\hline 8. & Shalaparni & Desmodium gangeticum & Roots \\
\hline 9. & Prishniparni & Uraria picta & Roots \\
\hline 10. & Kasmarya & Gmelina arborea & Roots \\
\hline 11. & Chitraka & Plumbago zeylanica & Roots \\
\hline 12. & Pushkara moola & Inula racemose & Roots \\
\hline 13. & Lodhra & Symplocos racemose & Stembark/ Roots \\
\hline 14. & Guduchi & Tinospora cordifolia & Stem \\
\hline 15. & Amalaki & Phyllanthus emblica & Fruit \\
\hline 16. & Duralabha & Fagonia cretica & whole plant \\
\hline 17. & Khadira & Acacia catechu & Heart wood \\
\hline 18. & Bijasara & Pterocarpus marsupium & heart wood \\
\hline 19. & Pathya & Terminalia chebula & Fruit \\
\hline 20. & Kushta & Saussurea lappa & Root \\
\hline 21. & Manjishta & Rubia cordifolia & Root \\
\hline 22. & Devadaru & Cedrus deodara & Heart wood \\
\hline 23. & Vidanga & Embelia ribes & Fruit \\
\hline 24. & Madhuka & Madhuca longifolia (Koen.) & Root \\
\hline 25. & Bharngi & Clerodendrum serratum & Root \\
\hline 26. & Kapittha & Feronia limonia & Fruit \\
\hline 27. & Bibhitaka & Terminalia bellirica & Fruit \\
\hline 28. & Punarnava & Boerhavia diffusa & Root \\
\hline 29. & Chavya & Piper retrofractum & Stem \\
\hline 30. & Jatamansi & Nordostachys jatamansi & Rhizome \\
\hline 31. & Priyangu & Callicarpa macrophylla & Flower \\
\hline 32. & Sariva & Hemidesmus indicus & Root \\
\hline 33. & Krishnajeeraka & Carum carvi & Fruit \\
\hline 34. & Trivrit & Operculina turpethum & Root \\
\hline 35. & Nirgundi & Vitex negundo & Seed \\
\hline 36. & Rasna & Pluchea lanceolate & Leaf \\
\hline 37. & Pippali & piper longum linn & Fruit \\
\hline 38. & Puga & Areca catechu & Seed \\
\hline 39. & Shati & Hedychium spicatum & Tubers \\
\hline
\end{tabular}




\begin{tabular}{|c|c|c|c|}
\hline 40. & Haridra & Curcuma longa & Rhizome \\
\hline 41. & Shatapushpa & Anethum sowa & Fruit \\
\hline 42. & Padmaka & Prunus cerasoides & Stem \\
\hline 43. & Nagakesara & Mesua ferrea & Stamen \\
\hline 44. & Musta & Cyperus rotundus & Rhizome \\
\hline 45. & Indrayava & Holarrhena antidysenterica & Seeds \\
\hline 46. & Shunthi & Zingiber officinalis & Rhizome \\
\hline 47. & Jivaka & $\begin{array}{l}\text { Malaxis acuminta D.Don syn. } \\
\text { Microstylis wallichii Lindl syn. Malaxis wallichii Deb. }\end{array}$ & Stem \\
\hline 48. & Risabhaka & Microstylis muscifera Ridley & Root \\
\hline 49. & Meda & $\begin{array}{l}\text { Polygonatum verticillatum (L.) } \\
\text { All. syn. Convallaria verticillata L. syn Evallaria verticillata Necker }\end{array}$ & Root \\
\hline 50. & Mahameda & Polygonatum cirrhifolium (Wall.) Royle & Root \\
\hline 51. & Kakoli & $\begin{array}{l}\text { Roscoea procera Wall. formerly Roscoea purpurea or Fritil- } \\
\text { laria roylei Hook.f }\end{array}$ & Root \\
\hline 52. & Kshirakakoli & Lilium polphyllum D.Don & Root \\
\hline 53. & Riddhi & Habenaria edgeworthii H.f. & Root \\
\hline 54. & Vriddhi & Habenaria intermedia D.Don syn. Habenaria arietina H.f. & Root \\
\hline
\end{tabular}

Table 5: Composition of Kwatha Dravya of Draksha

\begin{tabular}{|r|l|l|l|}
\hline S. No & Sanskrit Name & Latin Name & Parts Used \\
\hline 1. & Draksha & Vitis vinifera & Fruit \\
\hline 2. & Dhataki & Woodfordia fruticosa & Flower \\
\hline 3. & Guda & Jaggery & - \\
\hline 4. & Kshaudra & Honey & - \\
\hline
\end{tabular}

Table 6: Composition of Sukshma Churna Dravya

\begin{tabular}{|c|l|l|l|}
\hline S. No & Sanskrit Name & Latin Name & Parts Used \\
\hline 1. & Kankola & Piper cubeba & Fruit \\
\hline 2. & Jala & Coleus vettiveroides & Root \\
\hline 3. & Chandana & Santalum album & Heart wood \\
\hline 4. & Jatiphala & Myristica fragrans & Seed \\
\hline 5. & Lavanga & Syzygium aromaticum & Flower bud \\
\hline 6. & Tvak & Cinnamomum zeylanicum & Stem bark \\
\hline 7. & Ela & Elettaria cardamomum & Seed \\
\hline 8. & Patra & Cinnamomum tamala & Leaf \\
\hline 9. & Kesara & Crocus sativus & Threads of flowers \\
\hline 10. & Pippali & Piper longum & Fruits \\
\hline 11. & Kataka Phala & Strychnos potatorum & Seed \\
\hline 12. & Kasturi & Moschus moschiferus & Secretion \\
\hline & & & \\
\hline
\end{tabular}

\section{Method of Preparation}

1. Dashamoola Kwatha ${ }^{8}$ : According to Bhaisajya Ratnavali, 01 Pala (48gm) of coarsely powdered drugs is boiled with 16 parts of water in an earthen pot, over a mild fire till the liquid is reduced to $1 / 8$ of quantity. Finally, the liquid should be strained through cloth.

2. Dasamoolarishta': According to Sarngadhara Samhitha, mixing the Dasamoola Kwatha with the form of Yavakuta Churna of Dasamoola, Kwatha 
of Draksha and Guda, Madhu, Dhataki Pushpa followed by Prakshepa Dravya in Sandhana Patra. Thereafter it is sealed properly and kept undis- turbed. On the completion of the fermentation process, Kataka Bija is added to clear the liquid and filter the same. Finally, Kasturi is added to the filtered liquid.

Table 7: Different Varieties of Dasamoola Kwatha and Anupana mentioned in Ayurveda

\begin{tabular}{|c|c|c|c|}
\hline No & Ingredients & Anupana & Therapeutic benefits \\
\hline 1. & Dasamoola ${ }^{10}$ & Pippali powder & Controls diseases of throat (Kantagraha) and heart (Hrid graha) \\
\hline 2. & $\begin{array}{l}\text { Dasamoola, Bala, Rasna, } \\
\text { Puskaramula, Devadaru } \\
\text { and Shunthil }\end{array}$ & - & $\begin{array}{l}\text { Provides relief from Parsavasoola, Skandasoola (pain in the } \\
\text { shoulders) headache and other disorders like Kasa (cough) etc. } \\
\text { caused from tuberculosis }\end{array}$ \\
\hline 3. & $\begin{array}{l}\text { Dasamoola } \\
\text { and Pippali }\end{array}$ & $\begin{array}{l}\text { 1gm of pepper } \\
\text { powder }\end{array}$ & $\begin{array}{l}\text { The confection is an excellent recipe for the cure of Kaphaja type } \\
\text { of Kasa, fever, bronchitis and pleurisy }\end{array}$ \\
\hline 4. & Dasamoola $^{13}$ & Honey & It cures Sutika problems \\
\hline 5. & Dasamoola $^{14}$ & $\begin{array}{l}1 \mathrm{~g} \text { of Puskara } \\
\text { roots powder }\end{array}$ & $\begin{array}{l}\text { Cures bronchitis, asthma, cases of pleurisy and pain in the cardiac } \\
\text { region. }\end{array}$ \\
\hline 6. & Dasamoola $^{15}$ & $\begin{array}{l}\text { Yavaksara } \\
(250 \mathrm{mg}) \text { and pow- } \\
\text { dered red rock salt } \\
(500 \mathrm{mg})\end{array}$ & In curing heart problems, Swasa, Gulma and Soola \\
\hline 7. & Dasamoola $^{16}$ & $\begin{array}{l}\text { salt and Kshara- } \\
\text { alkali preparation }\end{array}$ & $\begin{array}{l}\text { Cures Kasa (cough) asthma, heart diseases, Gulma (phantom tu- } \\
\text { mour) and colic pain. }\end{array}$ \\
\hline 8. & Dasamoola $^{17}$ & $\begin{array}{l}\text { Purified Silajathu } \\
1 \text { gm and jaggery } \\
12 \mathrm{gm} .\end{array}$ & $\begin{array}{l}\text { Cures such diseases as Vata Kundalika, Asthila and Vata Vasti } \\
\text { (wind entered through enema) }\end{array}$ \\
\hline 9. & Dasamoola 18 & - & For Vatika type of Oedema \\
\hline 10. & Dasamoola $^{19}$ & $\begin{array}{l}\text { Puskara } \\
\text { powder }\end{array}$ & Gridhrasi Vata \\
\hline
\end{tabular}

\section{Results}

Table 8: Difference between Dashamoola Kwatha and Dasamoolarishta

\begin{tabular}{|c|c|c|c|}
\hline S.No & Features & Dashamoola Kwatha & Dasamoolarishta \\
\hline 1. & $\begin{array}{l}\text { Generation of } \\
\text { alcohol }\end{array}$ & No self-generated alcohol & Contains about $8-12 \%$ of self-generated natural alcohol in it. \\
\hline 2. & Dose & Usually the dose is $50 \mathrm{ml}$ & $12-24 \mathrm{ml}$. One or two times a day, usually advised after food. \\
\hline 3. & Efficacy & $\begin{array}{l}\text { Efficacy of the drug is reduced } \\
\text { with the time. }\end{array}$ & $\begin{array}{l}\text { Efficacy of the drug is not reduced with the time, usually it is } \\
\text { increased. }\end{array}$ \\
\hline 4. & $\begin{array}{l}\text { Rasayana } \\
\text { guna }\end{array}$ & $\begin{array}{l}\text { No specifically identified } \\
\text { Rasayana guna. }\end{array}$ & $\begin{array}{l}\text { The medicine is a great Rasayana as well. } \\
\text { It improves immunity and strength. } \\
\text { It is used as a general health tonic }\end{array}$ \\
\hline 5. & Side Effects & No side effects identified & High dose may cause burning sensation, stomach disturbances. \\
\hline 6. & $\begin{array}{l}\text { Contra indi- } \\
\text { cations }\end{array}$ & $\begin{array}{l}\text { Not contraindicated during } \\
\text { pregnancy. }\end{array}$ & It is not prescribed as a tonic during pregnancy. \\
\hline
\end{tabular}

Dasamoola Kwatha promotes digestive power and it cures Kantharoga (diseases of throat). (B.R.165), $\mathrm{Va}$ - takapha Jwara, Sannipata Jwara, Sutika Dosa (diseases of puerperal woman), Sosha (emaciation), Saitya, Bhrama (dizziness), Sweda (Hyperhidrosis), Kasa 
(cough), Swasa (breathlessness), Hridroga (diseases of heart), Parshwa Shula (pain in flank region), Tandra (drowsiness), Mastaka Sula (headache). ${ }^{20}$

Dasamoolalarishta is capable of alleviating many diseases in all the system of human body. It cures Grahani(Malabsorption syndrome), Mandagni (dyspepsia), Aruchi (anorexia), Chardi (vomiting), Bhagandara (anal fistula), Kasa (cough), Gulma (sprue or silosis), Vata Vyadi (Vata imbalance disorders), Pandu Roga (Anemia), Kamala (liver disorders, jaundice), Kushtha (skin disorders), Arsas (Piles), Prameha (Diabetes), Udara (Ascites), Mutra Sarkara (urinary gravels), Asmari (urinary calculi), Mutrakricchra (difficulty in urination), Dhatu Kshaya (in emaciated, lean and weak person) and Meha (urinary disorders). ${ }^{21}$

\section{Advantages of fermented liquors of $\mathrm{Da}$ - samoolarishta:}

Ancient Ayurvedic teachers have invented Sandhana kalpana to increase absorption of active principles of herbs more to the human body when they are dissolved in a fermented base. Delivering medicaments to the body is higher in Dasamoolarishta which enhances the therapeutic benefits. Therefore, it is more beneficial to use Dasamoolarista than Dasamoola Kwatha. ${ }^{22}$

Also, Arishta is a herbarized wine, possessed with many medicinal qualities prescribed for varieties of ailments. These are generally delicious in taste and should be taken appropriately under guidance of a physician in adequate amount and duration without exceeding the prescribed volume.

\section{DISCUSSION}

Kwatha and Arishta are the most suitable dosage forms of Dasamoola for the treatment of relevant disease conditions. Traditional uses of different varieties of $\mathrm{Da}$ samoola Kwatha have been designed specifically to address the particular individualized disease condition. Use of different varieties of Dasamoola Kwatha clearly shows a relationship between symptoms of illnesses and various forms of Dasamoola Kwatha prepared with different ingredients.

Ashtavarga is one of the most important ingredients in the Kwatha Dravya of Dasamoolarista which is having the properties of Jeevaniya and Vayasthapana. The herbs in the Ashtavarga are Jeevaka, Rishbhaka, Meda, Mahameda, Kakoli, Kshira-kakoli, Riddhi and Vriddhi. pharmacological actions of these can be compared with nutritive, antioxidant and anti-ageing effects. Therefore, Dasamoolarista by design gets all the qualities and pharmacological actions of Ashtavarga in it. ${ }^{23}$ Dashamularishta is a general health tonic and it improves immunity and strength. One of the most important advantageous outcomes of natural fermentation process of Dashamularishta is self-generating alcohol in it. This self-generated alcohol and the water present in the product acts as a media to deliver water and alcohol soluble active herbal components to the body. Therefore, the qualities of Dasamoola have been enhanced and produced multiple actions towards all the systems. Furthermore, this alcoholic base stabilizes this pharmaceutical product and protects its physical, chemical and therapeutic specifications by avoiding the microbial contamination.

With regard to the moderate alcohol consumption, it is advised to take up to one drink per day for women and up to two drinks per day for men. To make equation for moderate alcohol consumption in female, one should take $5 \mathrm{fl}$. oz of $12 \%$ alcohol (reference beverage). ${ }^{24}$ Dosage of Dasamoolarishta per day is $40-80 \mathrm{ml}^{25}$ $30 \mathrm{ml}$ of liquid

$=$ One fluid ounce

$80 \mathrm{ml}$ of Dasamularishta

$=1$. fl.oz/ $30 * 80$

$=2.66 \mathrm{fl} . \mathrm{Oz}$

Dasamoolarista daily dosage does not exceed the moderate alcohol consumption level and it provides more health benefits due to its natural fermentation process. Thus, it can lower risk of Cardiovascular diseases by raising levels of high-density lipoprotein (HDL) as higher HDL levels are associated with greater protection against heart diseases. Also, it can promote the life span by reducing the risk of death by $18 \%$. Furthermore, Dasamoolarista improves libido by protecting against erectile dysfunction. Also, it can be helpful to prevent Common Cold and to decrease chances of developing Dementia. Moreover, Dasamoolarista can reduce the risk of Gallstones and lower the chance of type II Diabetes Mellitus. ${ }^{26}$ 


\section{CONCLUSION}

It is very useful to choose a suitable formula of $D a$ samoola kwatha in each disease condition where the drug is appropriate. Also, it is necessary to take Anupana of Dasamoola Kwatha into account in each disease condition.

In comparison with Dasamoola Kwatha, Dasamoolarishta is more active in every system of the body and its lingering capacity makes easier to treat patients who need it. Also, its number of therapeutic actions is higher when compared to Dasamoola Kwatha.

\section{REFERENCES}

1. Patil, V.C., Rajeshwari, N.M. (2018), Sushruta Samhita, Sutra Sthana. Vol. I. Varanasi: Chaukhamba Publications; Chapter 38. p. 400-401

2. Bhisagratna, G.D. (2016), English Translation by Lochan, K. Bhaisajya Ratnavali, Vol. I. New Delhi: Chaukhamba Publications; Chapter 05. p. 165-166

3. Rao, G.P. (2016) Sarngadhara Samhita Chaukhambha Publications: New Delhi Chapter 10. p.205-207

4. Patil, V.C., Rajeshwari, N.M. (2018), Sushruta Samhita, Sutra Sthana. Vol. I. Varanasi: Chaukhamba Publications; Chapter 38. p. 400-401

5. Patil, V.C., Rajeshwari, N.M. (2018), Sushruta Samhita, Sutra Sthana. Vol. I. Varanasi: Chaukhamba Publications; Chapter 38. p.401

6. Patil, V.C., Rajeshwari, N.M. (2018), Sushruta Samhita, Sutra Sthana. Vol. I. Varanasi: Chaukhamba Publications; Chapter 38. p. 401

7. Rao, G.P. (2016) Sarngadhara Samhita, Chaukhambha Publications: New Delhi Chapter 10. p.194-207

8. Bhisagratna, G.D. (2016), English Translation by Lochan, K. Bhaisajya Ratnavali, Vol. I. New Delhi: Chaukhamba Publications; Chapter 05. p. 165-166

9. Rao, G.P. (2016) Sarngadhara Samhita, Chaukhambha Publications: New Delhi Chapter 10. p.207

10. Bhisagratna, G.D. (2016), English Translation by Lochan, K. Bhaisajya Ratnavali, Vol. I. New Delhi: Chaukhamba Publications; Chapter 05. p. 166

11. Bhisagratna, G.D. (2016), English Translation by Lochan, K. Bhaisajya Ratnavali, Vol. I. New Delhi: Chaukhamba Publications; Chapter 14. p. 774

12. Bhisagratna, G.D. (2016), English Translation by Lochan, K. Bhaisajya Ratnavali, Vol. I. New Delhi: Chaukhamba Publications; Chapter 15. p. 833
13. Bhisagratna, G.D. (2016), English Translation by Lochan, K. Bhaisajya Ratnavali, Vol. III. New Delhi: Chaukhamba Publications; Chapter 69. p. 399

14. Bhisagratna, G.D. (2016), English Translation by Lochan, K. Bhaisajya Ratnavali, Vol. II. New Delhi: Chaukhamba Publications; Chapter 16. p. 07

15. Bhisagratna, G.D. (2016), English Translation by Lochan, K. Bhaisajya Ratnavali, Vol. II. New Delhi: Chaukhamba Publications; Chapter 29. p. 335

16. Bhisagratna, G.D. (2016), English Translation by Lochan, K. Bhaisajya Ratnavali, Vol. II. New Delhi: Chaukhamba Publications; Chapter 33. p. 441

17. Bhisagratna, G.D. (2016), English Translation by Lochan, K. Bhaisajya Ratnavali, Vol. II. New Delhi: Chaukhamba Publications; Chapter 35. p. 475

18. Bhisagratna, G.D. (2016), English Translation by Lochan, K. Bhaisajya Ratnavali, Vol. II. New Delhi: Chaukhamba Publications; Chapter 42. p. 643

19. Rao, G.P. (2016) Sarngadhara Samhita, Chaukhambha Publications New Delhi Chapter 02. p.89

20. Rao, G.P. (2016) Sarngadhara Samhita, Chaukhambha Publications New Delhi Chapter 02. p.77

21. Rao, G.P. (2016) Sarngadhara Samhita, Chaukhambha Publications New Delhi Chapter 02. p.207

22. Chaudary, A., Singh, N., Dalvi, M., Wele, A. (2011): AYU Journal: progressive review of Sandhana kalpana (Biomedical fermentation): An advanced innovative dosage form of Ayurveda: 2011 Jul-Sep 2011

23. Dr Amrit Pal Singh, MD (Alternative Medicine), Herbal Consultant. Ind Swift Ltd, Chandigarh. AshtavargaRare Medicinal Plants, Ethnobotanical Leaflets 10: 104108. 2006. Issued 3 April 2006

24. Dietary Guidelines 2015-2020, Key Elements of Healthy Eating Patterns, Chapter1

25. Rao, G.P. (2016) Sarngadhara Samhita, Chaukhambha Publications New Delhi Chapter 02. p.207

26. Bachai, S. Medical Daily: 7 Health Benefits of Drinking Alcohol: Jul 10, 2013

\section{Source of Support: Nil \\ Conflict of Interest: None Declared}

How to cite this URL: B. S. M. M. Sooriyaarachchi \& Vidya N. V \& D. B. Vaghela: Comparative Study Of Dasamoola Kwatha And Dasamoolarishta With Special Reference To Their Method Of Preparation And Uses. International Ayurvedic Medical Journal \{online\} 2020 \{cited July, 2020\} Available from: http://www.iamj.in/posts/images/upload/3896 3902.pdf 